\title{
Anti-tobacco postage stamps
}

Baton Rouge Clinic, 8415 Goodwood Boulevard Baton Rouge, Louisiana 70806-7899, USA J H Lutschg

James H Lutschg

The cover of this initial issue of Tobacco Control is a good news/bad news story. The good news is that there is an anti-tobacco stamp from at least one nation from each of the six regions of the world, as designated by the World Health Organisation. The bad news is that neither of the countries of origin of this journal's publisher or editor have produced an anti-tobacco postage stamp. The stamps of Argentina, Niger Republic, Mali, Portugal, Indonesia, and Tunisia were all issued on World Health Day in 1980 to support the theme "Smoking or Health-The Choice is Yours." Czechoslovakia issued its second antitobacco stamp in 1981. Japan followed in 1987 on the occasion of the sixth world conference on smoking and health, which was held in Tokyo.

George B Griffenhagen's review in the March-April 1981 issue of Topical Time discusses anti-tobacco stamps issued by the nations of the world, identifying the first such stamp to have been produced in Czechoslovakia in 1976. In addition to the 24 stamps issued in 1980 to observe the World Health Day theme of that year, another 26 stamps have been issued (table). Brazil issued its anti-tobacco stamp on World Health Day in 1991 (7 April), the Republic of Yemen issued its stamp on World No-Tobacco Day in 1991 (31 May), and Indonesia issued its second antitobacco stamp in 1991. To date, 43 countries have issued anti-tobacco stamps (counting Yemen once) (table).

In years gone by, as noted in the May-June 1989 issue of Philip Morris Magazine, the situation was quite different. The "PM Notebook" of that issue states, "From America to

Nations of the world that have issued anti-tobacco stamps and year of issue

\begin{tabular}{ll}
\hline Afghanistan 1980 & Kuwait 1980 \\
Argentina 1980 & Mali 1980 \\
Australia 1990 & Mexico 1980, 1990 \\
Belgium 1979 & Nozambique 1988 Republic 1980 \\
Bophuthatswana 1980 & Philippines 1980 \\
Brazil 1991 & Portugal 1980 \\
Bulgaria 1980 & Russia 1980 \\
Burundi 1990 & San Marino 1980, 1984 \\
Chile 1987 & Saudi Arabia 1980 \\
People's Republic of China & Senegal 1981 \\
1980 & Swaziland 1982 \\
Cyprus 1990 & Syria 1980 \\
Czechoslovakia 1976, 1981 & Taiwan, China 1989 \\
Ethiopia 1980 & Thailand 1976, 1980 \\
France 1980 & Tunisia 1980 \\
Germany 1984 & Turkey 1990 \\
Hungary 1980 & Uganda 1990 \\
Indonesia 1980, 1991 & Uruguay 1980 \\
Iraq 1980 & Yemen (People's Democratic \\
Israel 1983 & Republic of) 1988 \\
Italy 1982, 1984 & Yemen (Republic of) 1991 \\
Ivory Coast 1980 & Yugoslavia 1990 \\
Japan 1987 & \\
\hline
\end{tabular}

Australia, Greece to Ghana, countries have honored tobacco on a wide variety of stamps." The United States recognised in 1907 the 300th anniversary of the founding of Jamestown, the first permanent English colony in the United States, with a commemorative stamp. This stamp prominently displays tobacco. Likewise, issued in 1982 was the centenary issue honouring former US President Franklin Delano Roosevelt, who is pictured clutching his cigarette. Philip Morris Magazine has a photograph of this stamp accompanying the 1989 article, reflecting its pride in this honour of tobacco by the US Postal Service. Franklin D Roosevelt's death from cerebrovascular disease, and that of former US President Lyndon B Johnson, secondary to coronary artery disease, were certainly related to cigarette smoking. In Canada, where great progress is being made combating the tobacco epidemic, ${ }^{1}$ the Canadian Public Health Association still tries to get Canada Post to issue a stamp warning of the danger smoking presents.

Friedensreich Hundertwasser noted on the 35 th anniversary of the Declaration of Human Rights, "Postage stamps are the measure of the cultural standing of a country." A dozen years ago 24 nations demonstrated their cultural standing by selecting stamps for the 1980 commemoration of "Smoking or Health-The Choice is Yours." At about that time the US President, Jimmy Carter, was handpicking a block of four flower stamps that were issued in 1981 by the US Postal Service. During a 1978 visit to North Carolina, a major tobacco growing state, President Carter observed that "the tobacco industry, the tobacco farmers, the federal government, all citizens want to have an accurate and enlightened education program and research program to make the smoking of tobacco even more safe than it is today."

The tobacco industry recognised one of the first US postmasters, Thomas Beale, with his own cigar brand. More recently, Preston Tisch was the US Postmaster General until several years ago. His family has as one of its major assets, Loew's corporation, owner of Lorillard Tobacco. Lorillard has been a purveyor of tobacco since 1760 , the company that brought the US public Old Golds of "not a cough in a carload" fame, Kent with the asbestos laden Micronite filter, and, more recently, Newport, "alive with pleasure."

The official US Postal Service criteria dictate that stamps be issued to commemorate 50th anniversaries and subsequent anniversaries at 50 year intervals. This is a flexible 
rule, however, since Mount Rushmore and the St Lawrence Seaway were both honoured on their 25th anniversaries. Most recently 1989 marked the 25th anniversary of the release of the first Surgeon General's report on smoking and health. This was not honoured with a commemorative stamp; however, during that same year the 20th anniversary of the moon landing was. As the rest of the world, and particularly developing countries, demonstrate their concern with the issuance of anti-tobacco stamps, the United States declines to do so and also has become the number one exporter of cigarettes in the world. The exported products often do not carry the same level of warning that is required in the United States.

The US Postal Service suggests that through its stamps one is able to "peer into the timeless windows of a great nation's soul." Unfortunately, those windows remain clouded by tobacco smoke. The official position of the US Postal Service is that the Citizen Stamp Advisory Committee has considered proposals to feature a smoke-free society and a no smoking message, but it has not recommended that such stamps be issued.

The work of Great Britain's postal service is touted by the International Postal Services Corporation (Malverne, New York) with the proclamation, "Since the days of the Penny Black, the stamps of Great Britain have been setting philatelic standards around the world." Yet the United Kingdom, like the United States, has not issued an anti-tobacco stamp.

We are approaching the 250 th anniversary of the first clinical report of tobacco and cancer. ${ }^{3}$ In 1761 Dr John Hill published in
London his work on the association of snuff with malignancy, noting:

Whether or not polypusses, which attend Snufftakers, are absolutely caused by that custom; or whether the principles of the disorder were there before, and the Snuff only irritated the parts, and hastened the mischief, I shall not pretend to determine: but even supposing the latter only to be the case, the damage is certainly more than the indulgence is worth: for who is able to say, that the Snuff is not the absolute cause, or that he has not the seeds of such a disorder which Snuff will bring into action.

With respect to cancers of the nose, they are as dreadful and as fatal as any others... It is evident therefore that no man should venture upon Snuff, who is not sure that he is not so far liable to a cancer: and no man can be sure of that. ${ }^{4}$

Perhaps the British and US postal services could combine their efforts to commemorate this event.

1 Mahood G. Treating the tobacco epidemic like an epidemic: the road to effective tobacco control in Canada. In:
Durston $\mathrm{B}$, Jamrozik $\mathrm{K}$, eds. Proceedings of the seventh world conference on tobacco and health, 1st-5th April 1990 . Perth, Western Australia: Health Department of Western Australia, 1990: 88-97.

2 Califano JA. Governing America : an insider's report from the White House and Cabinet. New York: Simon and Schuster, 1981: 192-3.

3 Redmand DE Jr. Tobacco and cancer: the first clinical Redmand DE Jr. Tobacco and cancer: the fir
report 1761. N Engl $\mathcal{M}$ Med 1970; 282: 18-23.

4 Hill J. Cautions against the immoderate use of snuff....2nd ed. London: R Baldwin, 1761 : 34-6.

Fourteen of the anti-tobacco stamps issued in 1980 were reproduced in an article by Dr Robert Greenwald published in Medical Times (1983; 111 (7): 41). Other anti-tobacco stamps will be featured on the cover of future issues of Tobacco Control.-ED 